\title{
A COMMON THREAD SYMPOSIUM 27-29 SEPTEMBER 2019
}

\author{
Stella Lange
}

In September 2019, the annual symposium of the Costume and Textiles Association of New Zealand was hosted by The Suter Gallery Te Aratoi o Whakatū in Nelson. The Costume and Textiles Association's yearly symposium draws a varied audience, ranging from those in various academic fields, historians and dress researchers to practitioners speaking of their own practice and work. These academics, artisans, artists, craftspeople and activists are drawn to present their work to each other and an enthusiastic audience - all connected by a deep passion for textiles and their use.

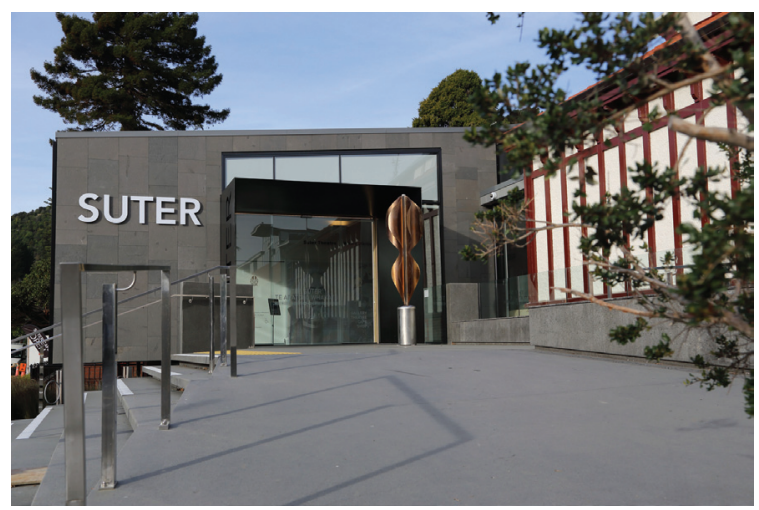

Figure I. Suter Gallery, Nelson.

The theme of the 2019 symposium, "A Common Thread," was drawn from the dictionary:

Common (adjective) - usual; ordinary; widespread; familiar; frequent; easily obtained, not rare; shared by, coming from, or done by two or more people, groups, or things; of the most familiar type; belonging to or involving the whole of a community or the public at large.

This theme accurately captured the space, place and prominence that clothing and textiles play in our everyday lives, as well as on special occasions and to mark notable events. To quote April Calahan and Cassidy Zachary, the hosts of the Dressed Podcast, "With over 7 billion people in the world, we all have one thing in common. Every day we all get dressed."'This year's symposium continued to deliver high-quality, interesting and personal stories about the relationships humans have with their clothing and textiles.

This review presents a snapshot of the wide range of presenters and equally diverse offering of papers at the 2019 symposium. The offerings spanned historical, contemporary, local, national and international aspects of costume and textiles. Four of the presentations are summarised in this short review - a difficult selection from such a culturally rich symposium. The four chosen represent the diversity common to all the CTANZ symposia and showcase the community engagement that characterises this organisation. Museum curators discussed emerging approaches to integrating digital printing into conservation and curation; local weavers shared stories telling how, as refugees from political oppression, they were fusing their traditional textile practices with electronics to create arts-based community installations; New Zealand historians revealed the ways in which the textile trade has layered over time along one of New Zealand's most iconic roads; and the histories and local knowledge embedded in contemporary Māori textile practices were revealed. 

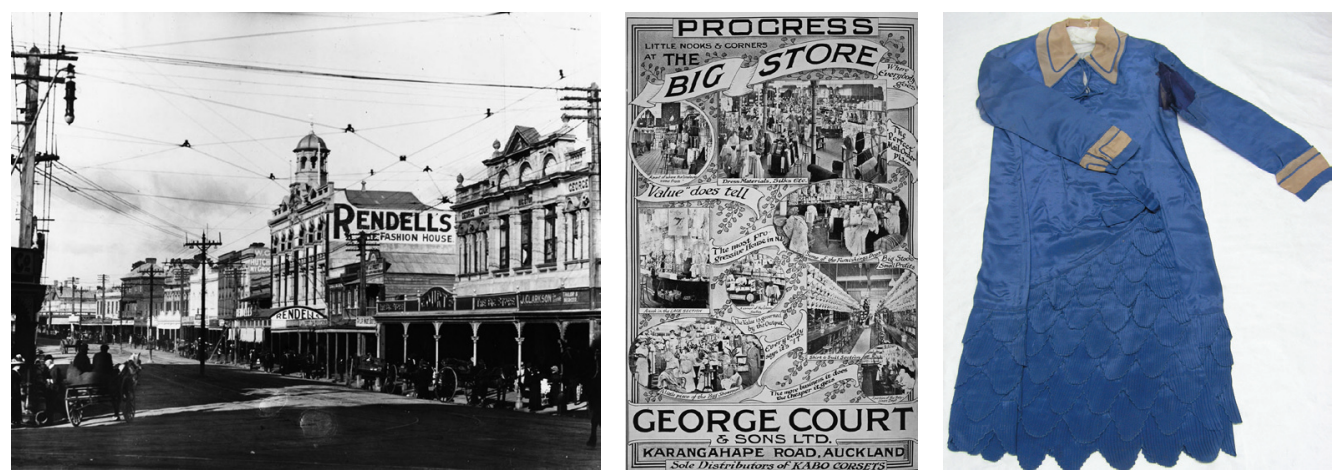

Figure 2. Karangahape Road: Sir George Grey Special Collections, Auckland Libraries, I-WI 307; George Court, Karangahape Road, (Auckland Libraries Heritage Collections AWNS-19|4|217-60- I);

Flackson Limited, Afternoon Dress, circa 1925, Collection of Auckland Museum, T666.

In "Clothes on the Road, a Textile Reading of Karangahape Road," Jane Groufsky spoke of a unique and important space in the collective history of New Zealand dress. Karangahape Road, or K-Road as it is more commonly called, was revealed as a unique space in the costume and fashion landscape of New Zealand. Groufsky presented an academic site analysis together with a nostalgic slideshow. Key players in Auckland's K-Road history were highlighted, from the 1920s department store Flacksons through to contemporary residents like the weaver Christopher Duncan of TūR. Groufsky, the Project Curator History at Auckland War Memorial Museum Tāmaki Paenga Hira, revealed a side of New Zealand costume history that is significant and timely, given the ongoing redevelopment of Auckland's central spaces.

Kate Douglas and Ellen Doyle, both conservators at the National Gallery of Victoria, discussed the display of eighteenth-century women's costume in their aptly named research paper, "I Don't Have the Stomacher for it."'The sophisticated museum curation and conservation practices followed at NGV were highlighted in this presentation. The presenters' research enabled the development of a digitally recreated stomacher for an eighteenth-century woman's dress that was missing that particular section. Women's dresses of the 1700s required a separate front panel, known as a stomacher, that was stiffened and used to fill in the centre front portion of the bodice - without this section the dress couldn't be displayed. Douglas and Doyle outlined their use of digital tools, technical collaborations and innovative methodologies in the design and production of a replica to replace and simulate the missing piece.The challenges relating to both applied practice and the curatorial ethics of recreating missing or fragile textiles as part of museum practice were openly discussed. The role of digitally created replicas in museum spaces is a new area for curators. Should replica textiles be "aged to match" or appear "as when they were new?" Do replicas need to be clearly identified or be presented as unobtrusively as possible? These were some of the many ethical questions the presenters discussed with the audience.

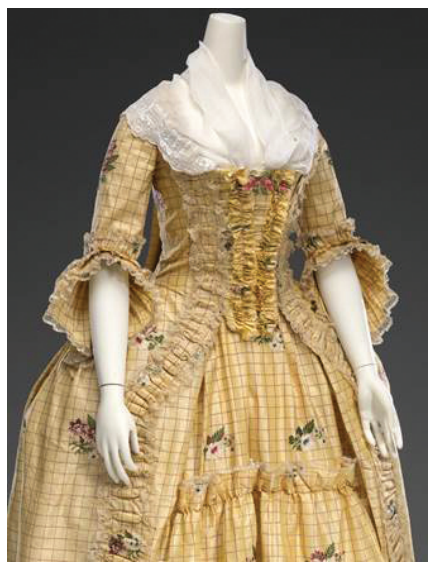

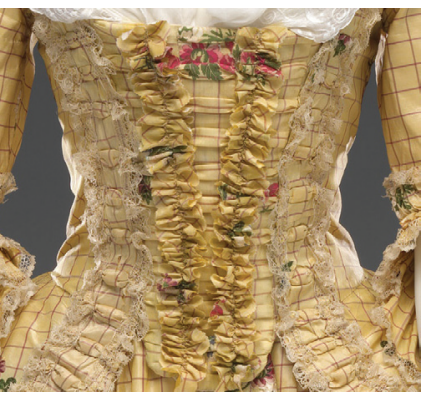

Figure 3. A digitally recreated stomacher for an eighteenth-century dress in the National Gallery of Victoria and detail. 
Chantelle Gerrard's talk opened a window on the hidden-in-plain-sight world of costuming for the the Pop-up Globe in Auckland. The insights she gave into her own research and practice revealed clear advantages for both costumer and actor in using traditional materials like linen and wool on the Shakespearian stage, instead of more modern fabrics and fabrications. Gerrard's hand-stitched costumes, cut using historically authentic patterns, were more comfortable and easier to maintain than synthetics for the frantic wardrobe department at the Pop-up Globe. Gerrard's research, visiting and collecting in England informed even the maintenance practices of the Pop-up Globe, where costumes were aired, brushed and even cleaned with vodka. These traditional methods proved surprisingly eco-friendly and low allergenic, and were preferred by cast and crew alike. The very real challenges of working with a tiny budget, the requirements of fast-paced theatre and of engaging and training a community of helpers were made clear in her talk - alongside her enthusiasm for her work. As wardrobe supervisor for over 60 productions, Gerrard shared information gleaned from her ongoing research trips to Europe to gather first-hand insights into Shakespearean-era garments and their construction and her practice as wardrobe manager for the Pop-up Globe.
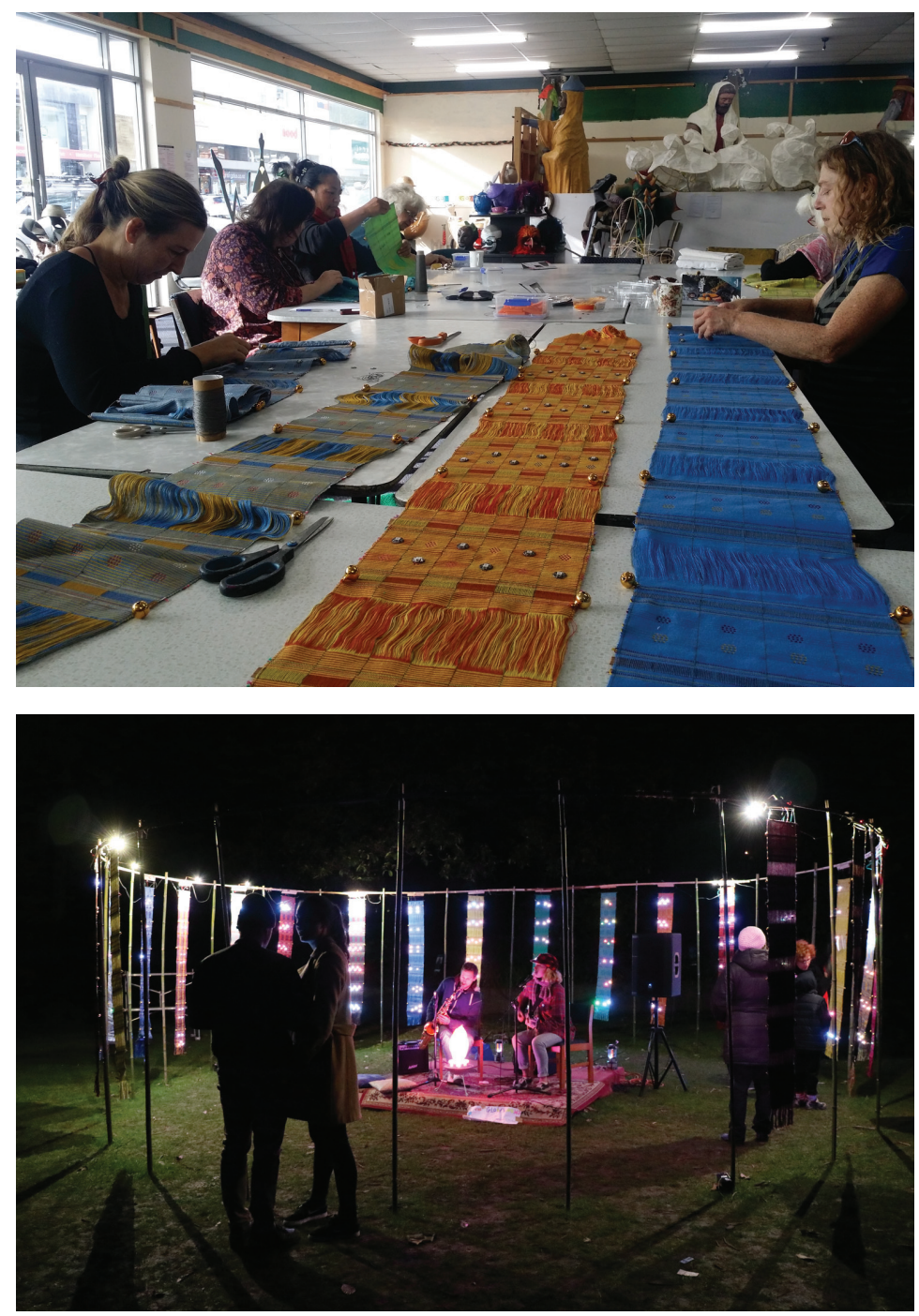

Figure 4.Volunteers sewing LEDs on banners for a digital light installation at the Camplight project.

Figure 5. A music event at the Camplight installation, with banners surrounding. 
Mu Bar, John-Paul Pochin and Dr Kay Sneddon shared their story with an attentive audience, providing insights on the 2016 Camplight project (a Light Nelson event). Mu Bar, a weaver of traditional tung (colourful Thai banners), spoke of her journey from Myanmar to living as a refugee in a Chinese-managed camp at Mae Hong Son in Thailand for two decades, and finally of coming to New Zealand. Throughout this time Mu Bar worked as a weaver, and in New Zealand she has set up a weaving collective with others from Myanmar. In the Camplight project, Mu Bar and other Kayan women weavers collaborated with John-Paul, a digital artist, and Dr Kay Sneddon to create a digital light installation designed to facilitate a cultural bridge between Kiwis and former refugees. Weaving, light projections and music combined in a month-long installation as part of Light Nelson, and provided a community space. Mu Bar spoke of the different roles that her weaving has played throughout her life, from household income to refugee tourism showcase in Mae Hong Son, to living as an independent artisan in New Zealand.

Hamuera Robb generously shared his knowledge of Māori kākahu weaving practices with his audience. His focus was on the practices used to create traditional kākahu (garments), with emphasis on the tools used and the use of local materials. The Māori science of making black dye and of using paru (iron-rich mud) in woven items was outlined. One concern he highlighted was the use of locally sourced paru, which provides a deep, intense colour, but also damages fibres. Being rich in iron, paru reacts with natural tannins and eventually degrades korowai. Using paru has implications in terms of design, longevity and curation. Robb's practice as a contemporary Māori weaver and historical researcher has enabled him to develop practices that make use of local paru in ways that are more stable than in the past. The requirements for storing and handling paru-dyed kākahu were discussed in light of kākahu's status as taonga in textile collections. Robb has a background as a traditional weaver and scholar. His Masters degree in Indigenous Knowledge /He Waka Hiringa from Te Wānanga o Aoteroa was granted for his research on clocks collected in the 1820s.

With over 23 separate presentations over three days, this review can only hint at the informed and interesting range of papers offered. Many of them will be published in Context:dress/fashion/textiles, the CTANZ journal. The Suter GalleryTe Aratoi o Whakatū provided a fantastic space for delegates, as well as several exhibitions. Local symposium organisers Andrea Barnard, Paula Haines-Bellamy, Jo Kinross, Moya Montgomery, Karen Richards and Pam Saunders provided an event that Bishop Suter, who established the gallery in 1900 as a "picture gallery for the people of Nelson," would have been proud of. In contemporary terms, Bishop Suter envisaged a space where creative activity would be available to all.

Post Covid-19, the 2020 Costume and Textiles symposium has been rescheduled for April 2021, and will be hosted by Auckland University of Technology. The theme will explore the concept of "Vision" in costume, fashion and textiles.

Stella Lange (@ORCID No 0000-0002-3676-433I) is a Principal Lecturer at the School of Design, Otago Polytechnic, and is co-chair of the Costume and Textiles Association of New Zealand. Her research field is the history of domestic textile repair and its use in education. She also maintains an applied practice in hand knitting, weaving and design. These various interests fit under an umbrella of sustainable practices, encouraging the responsible use and management of domestic textiles. 